\title{
Anti-apoptotic effects of 3,5,3'-tri-iodothyronine in mouse hepatocytes
}

\author{
O A Sukocheva and D O Carpenter ${ }^{1}$ \\ Division of Human Immunology, Signal Transduction Laboratory, Hanson Institute for Cancer Research, IMVS, Frome Road, Adelaide, South Australia 5000, \\ Australia \\ ${ }^{1}$ Department of Biometry and Statistics, School of Public Health, University at Albany, SUNY, One University Place, Rensselaer, New York 12144, USA \\ (Requests for offprints should be addressed to O A Sukocheva; Email: olga.sukocheva@imvs.sa.gov.au)
}

\begin{abstract}
The present study demonstrates that $3,5,3^{\prime}$-tri-iodothyronine $\left(\mathrm{T}_{3}\right)$ in physiological dose range inhibits tumor necrosis factor $\alpha(\mathrm{TNF} \alpha) /$ Fas-induced apoptosis in mouse hepatocytes. $\mathrm{T}_{3}$ pretreatment prevented Fas-induced early stage of apoptosis signs assessed by flow cytometry analysis of the annexin $\mathrm{V}$ positive cell population. $\mathrm{T}_{3}$ attenuated $\mathrm{TNF} \alpha / \mathrm{Fas}$-induced cleavage of caspase- 8 and DNA fragmentation. We found that $\mathrm{T}_{3}$ exerted its anti-apoptotic effects by mobilization of several non-genomic mechanisms independent of transcriptional activity. Inhibition of protein kinase A (PKA), extracellular signal-regulated kinase (ERK), and $\mathrm{Na}^{+} / \mathrm{H}^{+}$exchanger blocked $\mathrm{T}_{3}$-dependent anti-apoptotic effects indicating an involvement of these intracellular targets into $\mathrm{T}_{3}$-induced signaling cascade. Furthermore, physiological concentrations of $T_{3}$, but not reverse $T_{3}$, caused increases in intracellular
\end{abstract}

cAMP content and activated PKA. $\mathrm{T}_{3}$ markedly induced phosphorylation of ERK. We also detected $\mathrm{T}_{3}$-dependent intracellular alkalinization that abolished TNF $\boldsymbol{\alpha}$-induced acidification. PKA inhibitor KT-5720 blocked $\mathrm{T}_{3}$-induced activation of ERK and intracellular alkalinization confirming the upstream position of PKA signaling. We further detected that hepatocytes from hypothyroid mice are more sensitive to $\mathrm{TNF} \alpha /$ Fas-induced apoptosis than euthyroid animals in vivo. Together, these findings imply that $\mathrm{T}_{3}$ triggers PKA- and ERK-regulated intracellular pathways capable of driving and ensuring hepatocytes survival in the presence of death receptor ligand-induced damage under chronic inflammatory conditions.

Journal of Endocrinology (2006) 191, 447-458

\section{Introduction}

Thyroid hormones (THs) are widely known regulators of growth, metabolism, and development (Feng et al. 2000, Yen 2001, Davis \& Davis 2002). Multiple studies demonstrated that liver is an important target organ for THs. THs exerted mitogenic effects on hepatic metabolism, on the level of gene expression (Francavilla et al. 1994, Feng et al. 2000, Yen 2001) and on cell-cycle progression (Alisi et al. 2005, Furumoto et al. 2005). Majority of the functions of THs were mediated by the c-erbA proto-oncogenes - THs nuclear receptors, members of the steroid/thyroid hormone nuclear receptor subfamily that also function as ligand-modulated transcription factors (Yen 2001).

Beyond the abundant genomic effects, THs have been shown to initiate fast non-genomic signaling (Yen 2001, Davis \& Davis 2002, Incerpi 2005). It is important that most of plasma membrane and cytosol targets of THs have been strongly circumstantially linked to mitogenic and antiapoptotic signaling pathways (Qi et al. 1999, Laoag-Fernandez et al. 2004, Verga Falzacappa et al. 2006). For instance, THs were able to activate the $\mathrm{Na}^{+} / \mathrm{H}^{+}$exchanger (NHE) and reduce intracellular acidity produced by activated sodium

currents in different cells (Wang et al. 2003, D'Arezzo et al. 2004). THs induced activation of protein kinase C (PKC), protein kinase A (PKA), and mitogen activated protein kinase (MAPK) via putative G-protein-coupled receptor (GPCR; Lin et al. 1999, Yen 2001, D'Arezzo et al. 2004). Activation of the MAPK cascade by physiological concentrations of THs caused translocation of phosphorylated extracellular signalregulated kinase (ERK) to the cell nucleus resulting in serine phosphorylation of the nuclear THs receptor (TR) and transcriptional activity (Yen 2001, Davis \& Davis 2002, Shih et al. 2004).

THs may also exert a fast permissive action on the target cells' responsiveness to other active peptide and hormones. The status of THs modulated the steady-state levels of specific G-proteins induced by $\beta$-adrenergic agonists (Daza et al. 1997). It has also been shown that THs positively regulated epidermal growth factor receptor signaling pathway (Lin et al. 1999, Di Fulvio et al. 2000, Shih et al. 2004) - established survival regulator of Fas-induced apoptosis (Gibson et al. 1999). However, the effects of THs on Fas-induced apoptosis in hepatocytes have not yet been addressed.

Death receptor ligands (DRLs) have been demonstrated to impact hepatocellular damage (Zang et al. 2000, Ding \& Yin 
2004). Hepatocyte apoptosis initiated by DRLs like tumor necrosis factor- $\alpha(\mathrm{TNF} \alpha)$ or Fas contributed to a variety of liver diseases, including acute liver failure, viral and inflammatory hepatitis, alcoholic hepatitis, and ischemia/ reperfusion injury (Luedde et al. 2002, Ding \& Yin 2004). Several intriguing clues from clinical reports alluded to possible correlation between thyroid dysfunction and inflammation-related liver disorders. It was found that hepatitis sensitizes hepatocytes to TNF $\alpha$ apoptosis (Ding \& Yin 2004) and, on the other hand, is often accompanied by autoimmune hypothyroidism via impaired THs secretion (Antonelli et al. 2004). However, the possibility that hypothyroidism impacts the DRLs-dependent liver damage has not yet been explored given the demonstrated importance of TH status for liver regeneration (Alisi et al. 2005, Malik et al. 2005). Supporting the protective role of THs during liver injury, it has been shown that THs regulated the expression and activity of the proteins involved in the control of cell cycle, apoptosis, and growth arrest in hepatocytes after partial hepatoectomy (Malik et al. 2005). The analysis of the phosphorylated forms of MAPK, as survival and growth markers, revealed that they are induced during hepatic regeneration in euthyroid and hyperthyroid rats whereas they are negatively regulated in hypothyroid rats (Alisi et al. 2004). Therefore, considering in vivo and in vitro data, we questioned the ability of THs to influence hepatocyte survival signaling pathways.

The results of our experiments demonstrate that $T_{3}$ serves as an important anti-apoptotic factor in hepatocyte survival after DRLs-initiated apoptosis. $\mathrm{T}_{3}$ mobilizes several fastsignaling mechanisms and abrogates Fas/TNF-induced nuclear fragmentation and activation of caspase- 8 via increases in intracellular cAMP, induction of PKA and ERK, and maintenance of intracellular $\mathrm{pH}$ (pHin) in homeostasis.

\section{Materials and Methods}

\section{Chemicals}

3,5,3'-Tri'-iodothyronine $\left(\mathrm{T}_{3}\right)$, reverse $\mathrm{T}_{3} \quad\left(\mathrm{rT}_{3}\right)$, and 8-bromoadenosine $3^{\prime}, 5^{\prime}$-cyclic monophosphate (Br-cAMP) were purchased from Calbiochem (San Diego, CA, USA). MEK-1 inhibitor, U0126, was purchased from Cell Signaling Technologies (Beverly, MA, USA). bis carboxyethyl-5-(6)carboxyfluorescein (BCECF/AM), 5-(N-ethyl- $N$-isopropyl)amiloride (EIPA), actinomycin D (ActD), forskolin, amiodarone, KT-5720 (PKA inhibitor), cycloheximide, staurosporine (StSp), and digitonin were purchased from Sigma. Mouse TNF $\alpha$ and anti-Fas antibodies (clone Jo2) were purchased from Pharmingen (San Diego, CA, USA). Fas receptor, phospho-ERK ( $\mathrm{pERK}$ ), and ERK total antibodies were purchased from Santa Cruz Biotechnology (Santa Cruz, CA, USA). Anti-Fas-associated death domain-like interleukin 1beta-connecting enzyme-inhibitory protein (FLIP) CT polyclonal antibodies were from StressGen Biotechnology
(Victoria, BC, Canada). The anti-caspase- 8 antibody that recognizes the $18 \mathrm{kDa}$ active fragment of caspase- $8(\mathrm{p} 18)$ was from Oncogene Research Products (Boston, MA, USA). Unless otherwise specified, the rest of the chemicals used in this study were obtained from Sigma.

\section{Animals and hepatocyte culture experiments}

Mouse liver and primary hepatocyte cultures have been widely used for Fas-induced apoptosis studies (Fladmark et al. 1997, Ding \& Yin 2004). Wild-type male mice 8-weeks of age were assigned to one of the following groups: (a) euthyroid (sham operated); (b) hypothyroid that had been thyroidectomized surgically, allowed to stabilize, and used only if they had gained no weight for a minimum of 1 week prior to hepatocyte preparation or further treatment. The Fas-injury model group received a single i.p. injection of $0 \cdot 15 \mu \mathrm{g} / \mathrm{g}$ body weight Jo2 anti-Fas antibody (PharMingen, Franklin Lakes, NJ, USA) or $\mathrm{TNF} \alpha(0 \cdot 1 \mu \mathrm{g} / \mathrm{g}$ body weight) 6 or $10 \mathrm{~h}$ before liver extraction. Animals were placed under inhaled isoflurane anesthesia for isolation of blood and liver tissue. Plasma was prepared from whole blood by centrifugation at $4000 \mathrm{~g}$ for $30 \mathrm{~min}$ at $4{ }^{\circ} \mathrm{C}$. Plasma levels of alanine aminotransferase (ALT) and aspartate aminotransferase (AST) were measured by routine clinical chemical methods using enzyme assay kits as described previously (Zang et al. 2000). The concentrations of THs $\left(\mathrm{T}_{4}\right.$ and $\left.\mathrm{T}_{3}\right)$ in mouse blood were measured as previously described (Escobar-Morreale et al. 1996). Experiments with mice were conducted according to the National Research Council's guidelines for the care and use of laboratory animals.

For in vitro experiments, hepatocytes were isolated from male wild-type mice by the collagenase perfusion method (Francavilla et al. 1994). Briefly, livers were first perfused in situ with oxygenated $0.5 \mathrm{mM}$ EGTA in a calcium-free salt solution $\left(8 \mathrm{ml} / \mathrm{min}, 37{ }^{\circ} \mathrm{C}\right.$ for $\left.5 \mathrm{~min}\right)$, and then with a $0 \cdot 04 \%$ collagenase solution (Wako Pure Chemical Industries Co., Osaka, Japan) for $10 \mathrm{~min}$. Livers were then gently minced and filtered through a polyamide mesh. Hepatocyte viability was $>90 \%$, as determined by Trypan blue dye exclusion. Hepatocytes were diluted to a concentration of $2 \times 10^{5}$ cells/ $\mathrm{ml}$ and plated in 12-well plates $(1 \mathrm{ml} /$ well). The plates were previously coated with mouse collagen type I in Dulbecco's modified Eagle's medium (DMEM; GIBCO). The cells were cultured in DMEM containing 10\% fetal bovine serum, $2 \mathrm{mM}$ L-glutamine, $15 \mathrm{mM}$ HEPES ( $\mathrm{pH} 7 \cdot 4$ ), $100 \mathrm{U} / \mathrm{ml}$ penicillin, and $100 \mu \mathrm{g} / \mathrm{ml}$ streptomycin in a $5 \% \mathrm{CO}_{2}$ incubator at $37{ }^{\circ} \mathrm{C}$ for $16 \mathrm{~h}$ before various treatments. Hepatocytes were pretreated with vehicle or different concentrations of $\mathrm{T}_{3}$ for various time periods. For apoptosis induction, cells were treated with ActD $(0 \cdot 2 \mu \mathrm{g} / \mathrm{ml})$ and Jo2 $(0.5 \mu \mathrm{g} / \mathrm{ml})$ or recombinant mouse TNF $\alpha$ $(10 \mathrm{ng} / \mathrm{ml})$ as described previously (Ogasawara et al. 1993). We used a serum-free culture medium in in vitro experiments with hormones/inhibitors treatments so as to avoid the possible influences of various hormones contained in serum. 


\section{cAMP RIA}

Nearly confluent plates of cells, plated at a density $2 \times 10^{6}$ cells per $160 \mathrm{~mm}$ dish, were treated with various agents and then harvested in $500 \mu \mathrm{l}$ TNE media $(40 \mathrm{mM}$ Tris- $\mathrm{HCl}(\mathrm{pH}$ $7 \cdot 5), 140 \mathrm{mM} \mathrm{NaCl}$, and $1.5 \mathrm{mM}$ EDTA). Cells, collected into microcentrifuge tubes kept on ice, were pelleted $(100 \mathrm{~g}$ for $5 \mathrm{~min})$. The cell pellets were resuspended in $200 \mu \mathrm{l}$ ice-cold cAMP extraction buffer $(50 \mathrm{mM}$ Tris- $\mathrm{HCl}(\mathrm{pH} 7 \cdot 5)$ and $4 \mathrm{mM}$ EDTA). Extract aliquots were boiled for $10 \mathrm{~min}$, and cell debris was pelleted. The $\left[{ }^{3} \mathrm{H}\right]$ cAMP RIA kit (Amersham) was used to measure the cAMP content of samples. Incubations were carried out at $4{ }^{\circ} \mathrm{C}$ for $3 \mathrm{~h}$, and charcoal-dextran-treated samples were analyzed for radioactivity.

\section{PKA assay}

The cytosolic fractions that had been separated from cells after various treatments were used for protein kinase assays (Shih et al. 2004). The PKA activity was determined using a PKA Assay Kit, according to the manufacturer's directions (Upstate Biotechnology, Lake Placid, NY, USA). Briefly, cells were lysed, sonicated, centrifuged, and total protein was determined. A mixture of the cytosolic fraction $(5 \mu \mathrm{g}$ protein), assay dilution buffer ( $\mathrm{pH} 7 \cdot 2$ ), cAMP, PKC/ CaMK inhibitor cocktail, Mg/ATP $\left[\gamma-{ }^{32} \mathrm{P}\right]$ ATP $(5 \mu \mathrm{Ci}$ or $3000 \mathrm{Ci} / \mathrm{mmol}$ ), and Kemptide (a synthetic peptide containing the consensus PKA phosphorylation sequence) as substrate was incubated at $30^{\circ} \mathrm{C}$ for $10 \mathrm{~min}$, in a total volume of $60 \mu \mathrm{l}$. A $25 \mu \mathrm{l}$ aliquot of the reaction mixture was applied to phosphocellulose filter paper (Whatman p81) and washed repeatedly in $75 \mathrm{mM}$ phosphoric acid, and dried. The radioactivity was quantitated by scintillation. The results were expressed in terms of nanomoles phosphate/minute per milligram protein. The PKA assay was also performed in the presence of the protein kinase inhibitor peptide of PKA. These values were similar to background counts obtained in the absence of Kemptide substrate, indicating the specificity of the assay (data not shown).

\section{DNA fragmentation}

DNA fragmentation was demonstrated by harvesting total cellular DNA and $1 \cdot 2 \%$ agarose gel electrophoresis stained with ethidium bromide. Briefly, after the indicated treatment, both adherent and detached cells were harvested, washed with PBS, and lysed in $50 \mathrm{mM}$ Tris-EDTA (pH $7 \cdot 4), 1 \% \mathrm{SDS}$, and $0.5 \mathrm{mg} / \mathrm{ml}$ proteinase $\mathrm{K}$ for $3 \mathrm{~h}$ at $50{ }^{\circ} \mathrm{C}$. Samples were then extracted with phenol/chloroform and precipitated with ethanol. The pellet was resuspended in $20 \mathrm{mM}$ Tris-EDTA $(\mathrm{pH} 8 \cdot 0)$. After digesting RNA with RNase $(0 \cdot 1 \mathrm{mg} / \mathrm{ml})$ at $37{ }^{\circ} \mathrm{C}$ for $1 \mathrm{~h}$, DNA was separated by electrophoresis.

\section{Immunoblot analysis}

Cells were harvested and lysed by sonication in lysis buffer containing $50 \mathrm{mM}$ Tris- $\mathrm{HCl}$ (pH 7·4), 10\% glycerol, $0 \cdot 05 \%$ Triton X-100, $150 \mathrm{mM} \mathrm{NaCl}, 1 \mathrm{mM}$ dithiothreitol, $2 \mathrm{mM}$ $\mathrm{Na}_{3} \mathrm{VO}_{4}, 10 \mathrm{mM} \mathrm{NaF}, 1 \mathrm{mM}$ EDTA, and protease inhibitors (Roche Molecular Biochemicals). Protein concentrations in cell homogenates were determined with DCA protein assay (Bio-Rad) using BSA as standard. Proteins were normalized prior to gel loading. Aliquots of cell lysates were resolved by 8-12\% SDS-PAGE and transferred to Hybond-P membranes (Amersham). The membranes were then probed with appropriate antibodies according to the manufacturer's standard method. The immunocomplexes were detected with an enhanced chemiluminescence PLUS kit (Amersham Pharmacia Biotech). Densitometry was performed on a Typhoon 9410 Mode Imager using the ImageQuant program (Amersham).

\section{Annexin $V$ staining and analysis}

Annexin V-FITC binding to externalized phosphatidylserine has been used for apoptosis detection. Cells were plated in culture plates and exposed to various pretreatments. After apoptosis induction by Fas/TNF $\alpha / A c t D$, the cells were harvested, washed with ice-cold PBS, and subsequently resuspended and incubated (in the dark) with $100 \mu \mathrm{l}$ annexin $\mathrm{V}$ incubation reagent that includes FITC-conjugated annexin V (Trevigen, Gaithersburg, $\mathrm{MD}$, USA) and propidium iodide (PI) for $30 \mathrm{~min}$ at room temperature. Flow cytometry analyses were conducted using Epics XL-MCL flow cytometer (Coulter, Hialeah, FL, USA) at $488 \mathrm{~nm}$ wavelength. The percentage of apoptotic cells was determined as a percentage of annexin V-FITC-positive cells.

\section{Measurement of intracellular $\mathrm{pH}$}

Intracellular $\mathrm{pH}$ ( $\mathrm{pHin}$ ) was determined by fluorescence intensity of BCECF/AM (Sigma) using both flow cytometry and fluorimetry as described previously (Musgrove et al. 1986, D'Arezzo et al. 2004).

For fluorimetric determination, cells $\left(10^{8}\right.$ cells $\left./ \mathrm{ml}\right)$ were washed twice and then loaded with $1 \mu \mathrm{M}$ BCECF (in dimethylsulfoxide) for $30 \mathrm{~min}$ at $37{ }^{\circ} \mathrm{C}$ in the dark with gentle shaking in sodium HEPES buffer (D'Arezzo et al. 2004). Then the cells were washed twice and resuspended in the same buffer at $10^{6} \mathrm{cells} / \mathrm{ml}$, and introduced in a thermostatic cuvette at $37^{\circ} \mathrm{C}$ with constant stirring for the continuous recording of the $\mathrm{pH}$-sensitive fluorescence on a Perkin-Elmer LS50B luminescence spectrometer (Perkin-Elmer Corp., Norwalk, CT, USA). pHin was estimated from the ratio of the $530 \mathrm{~nm}$ fluorescence signals obtained at $500 \mathrm{~nm}$ (pH sensitive) and $450 \mathrm{~nm}$ (isosbestic) excitation wavelengths. Routinely at the end of each experiment, the calibration of fluorescence was carried out by established methods (Musgrove et al. 1986, D'Arezzo et al. 2004) in high potassium HEPES buffer containing the $\mathrm{H}^{+} / \mathrm{K}^{+}$ionophore 
nigericin $(10 \mu \mathrm{g} / \mathrm{ml})$. The calculations of ion concentration were carried out as described in Musgrove et al. (1986).

For cytofluorimetric pHin determination, cells were treated according to the designed protocol with or without hormones or inhibitors. The cells were then washed with media containing RPMI 1640, containing $10 \mathrm{mM}$ HEPES and $2 \cdot 5 \%$ serum, loaded with BCECF (as mentioned above), and analyzed using Epics XL-MCL flow cytometer as described previously (Musgrove et al. 1986). Excitation of the probe was performed at $488 \mathrm{~nm}$ with an argon laser. Emission fluorescence was filtered through a 525 band pass (green) and a 610 long pass (red) fluorescence filters.

\section{Statistical analysis}

All data are expressed as means \pm s.D. Unpaired Student's $t$ tests were used for comparison between two groups. For multiple comparisons, results were analyzed by ANOVA followed by the Dunnet's test. $P$ values $<0.05$ were considered statistically significant.

\section{Results}

Thyroid hormones suppress TNF $\alpha /$ Fas-induced apoptosis in mouse hepatocytes

In our experiments, mouse primary hepatocyte culture has been treated for $4 \mathrm{~h}$ with death receptor ligands (DRLs) - Fas $(0.5 \mu \mathrm{g} / \mathrm{ml})$ or $\mathrm{TNF} \alpha(10 \mathrm{ng} / \mathrm{ml})$ plus ActD $(0.2 \mu \mathrm{g} / \mathrm{ml}$; Fladmark et al. 1997, Ding \& Yin 2004). Apoptosis was assessed by flow cytometry detecting annexin $\mathrm{V}$ labeling of phosphatidylserine. DRLs-treated hepatocytes exhibited significantly increased annexin $\mathrm{V}$ binding (Figs 1 and 2).

The major form of THs secreted from thyroid gland is L-thyroxine $\left(\mathrm{T}_{4}\right)$; however, most of THs actions were induced by 3,5,3'-tri-iodothyronine $\left(\mathrm{T}_{3}\right)$ - the product of $\mathrm{T}_{4}$ deiodination (Yen 2001). We have assayed the effect of both $\mathrm{T}_{4}$ and $\mathrm{T}_{3}$ on Fas-induced apoptosis in hepatocytes. To detect the effect of $\mathrm{T}_{3} / \mathrm{T}_{4}$ on DRLs-induced apoptosis hepatocytes were pretreated with one of the hormones $(150 \mathrm{nM})$ or vehicle for $0 \cdot 25-6 \mathrm{~h}$ before stimulation with Fas/or TNF $\alpha$ / ActD. THs exposure decreased Fas and TNF $\alpha /$ ActD-induced
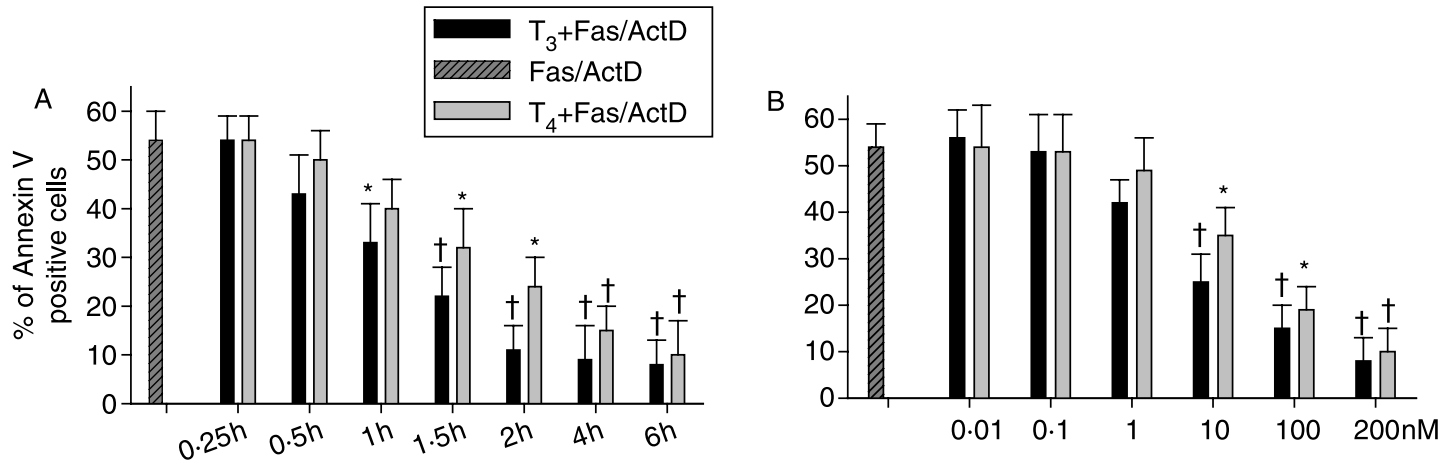

C
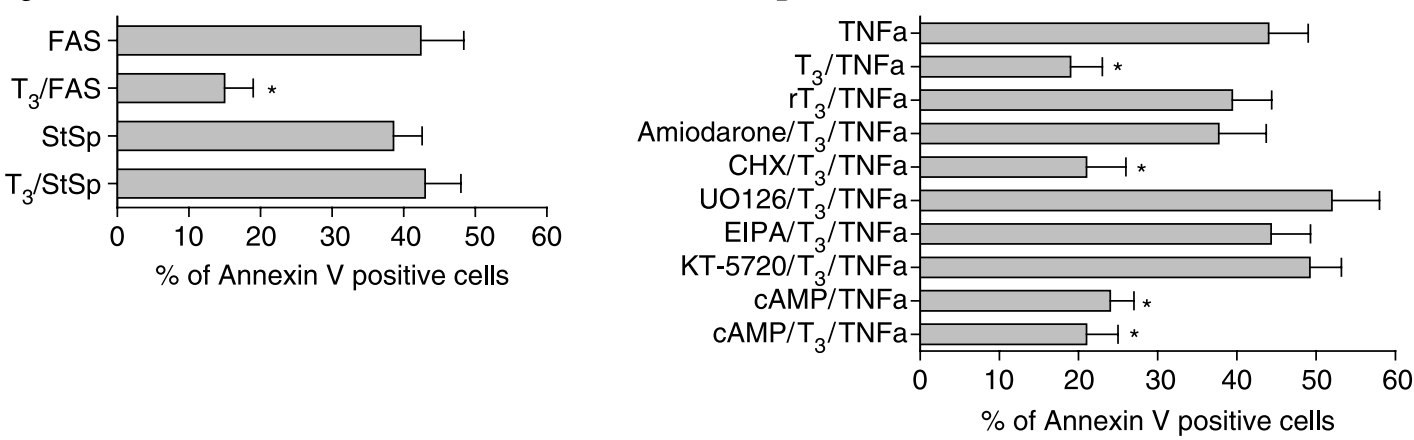

Figure $1 \mathrm{THs}\left(\mathrm{T}_{3}\right.$ and $\left.T_{4}\right)$ inhibit Fas-induced apoptosis in mouse hepatocytes. $(A) T_{3} / T_{4}(150 \mathrm{nM})$ time-dependent and (B) $T_{3} / T_{4}$ ( $2 \mathrm{~h}$ exposure) dose-dependent anti-apoptotic effects. Apoptosis has been detected by annexin $\mathrm{V}$ flow cytometry after $4 \mathrm{~h}$ stimulation with anti-Fas ligands $(0.5 \mu \mathrm{g} / \mathrm{ml})$ and ActD $(0.2 \mu \mathrm{g} / \mathrm{ml})$ as described in Materials and Methods. Values are expressed as means \pm s.D. ( $n=4$ for Fas-treated controls, while $n=8$ for $\mathrm{T}_{3} / \mathrm{T}_{4}$-pretreated groups) from four separate experiments. Statistically different data are marked as $* P<0 \cdot 05 ;{ }^{+} P<0 \cdot 01$ (Fas-treated versus $T_{3} / T_{4}$-pretreated cells). (C and D) $T_{3}$-induced preventive effects on Fas/TNF $\alpha$-induced apoptosis are independent of transcriptional and translational activities, but conditioned by PKA, $\mathrm{ERK}$, and intracellular $\mathrm{pH}$. The percentage of annexin V-positive cells is indicated. Used concentrations and time of treatment: $150 \mathrm{nM} \mathrm{T}_{3}$ or $\mathrm{rT}_{3}$ for $2 \mathrm{~h}$, TNF $\alpha(10 \mathrm{ng} / \mathrm{ml})$ or Fas $(0 \cdot 5 \mu \mathrm{g} / \mathrm{ml})+\operatorname{ActD}(0 \cdot 2 \mu \mathrm{g} / \mathrm{ml})$ for $4 \mathrm{~h} ; 1 \mu \mathrm{M}$ amiodarone; StSp $(1 \mu \mathrm{M})$ for $4 \mathrm{~h}$;

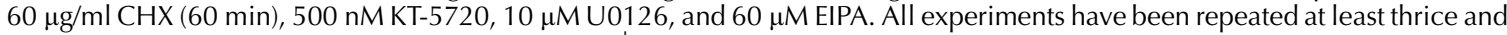
one representative experiment is shown. ${ }^{*} P<0 \cdot 05 ;{ }^{\dagger} P<0 \cdot 01$. 


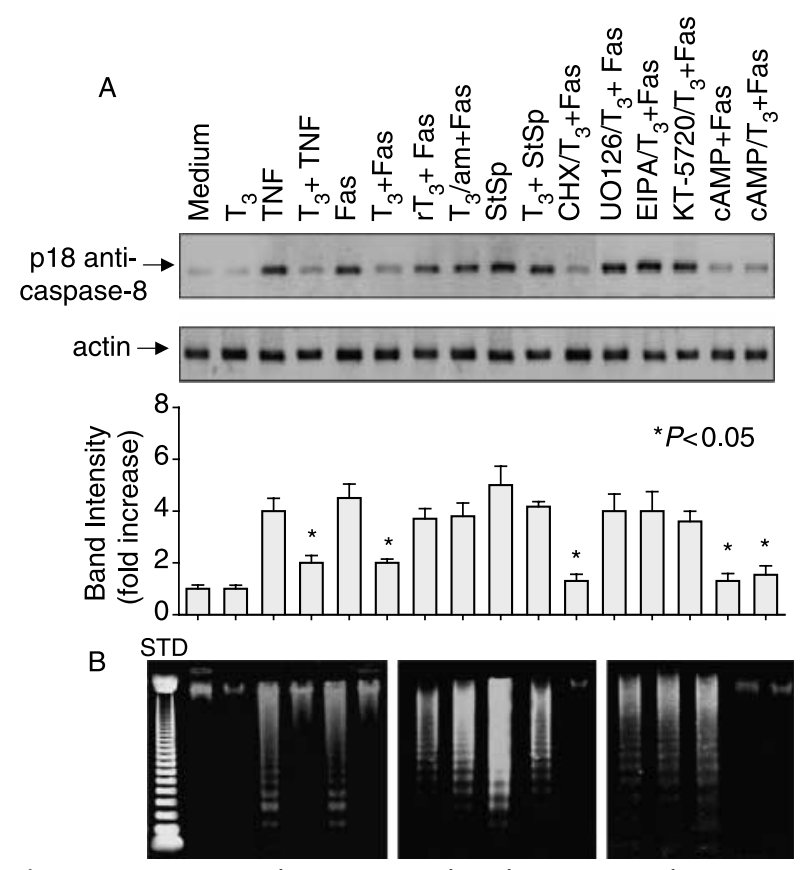

Figure $2 \mathrm{~T}_{3}$ prevented Fas/TNF $\alpha$-induced activation of caspase-8 and DNA degradation in mouse hepatocytes. (A) Hepatocytes were pretreated with the following agents separately or in combinations: $150 \mathrm{nM} \mathrm{T}_{3}$ or $\mathrm{rT}_{3}$ for $2 \mathrm{~h}$, TNF $\alpha(10 \mathrm{ng} / \mathrm{ml})$ or Fas $(0.5 \mu \mathrm{g} / \mathrm{ml})+$ ActD $(0 \cdot 2 \mu \mathrm{g} / \mathrm{ml})$ for $4 \mathrm{~h} ; 1 \mu \mathrm{M}$ amiodarone; StSp $(1 \mu \mathrm{M})$ for $4 \mathrm{~h} ; 60 \mu \mathrm{g} / \mathrm{ml}$ CHX (60 min), $500 \mathrm{nM} \mathrm{KT-5720,} 10 \mu \mathrm{M} \cup 0126$, and $60 \mu \mathrm{M}$ EIPA. Cell lysates were subjected to SDS-PAGE and caspase- 8 activation was detected by immunoblotting using anti-caspase- 8 antibody that recognizes the $18 \mathrm{kDa}$ active fragment of caspase-8 (p18). Equal protein loading was confirmed by actin staining of the blot. The bar graphs represent band intensities obtained from three individual experiments. Results were normalized by actin and expressed as means \pm s.D. ${ }^{*} P<0 \cdot 05$ versus medium (control). (B) Fragmented DNA was obtained from $5 \times 10^{5}$ cells as described in Materials and Methods and loaded in each lane. DNA ladder of 123 bp is marked as STD (standard). Experiment has been repeated four times. One representative experiment is shown.

apoptosis (Fig. 1). The preventive effect was also dose dependent and has been detected as early as $30-$ min $T_{3}$ pretreatment. $\mathrm{T}_{4}$ demonstrated effects similar to but lower than those induced by $T_{3}$. No protective effect was observed when $\mathrm{T}_{3}$ was simultaneously applied or post-applied after Fas/TNF $\alpha /$ ActD treatments. Application of reverse $\mathrm{T}_{3}\left(\mathrm{rT}_{3}\right)$ did not prevent DRL-induced apoptosis (Figs 1D and 2).

Structurally similar to biologically active THs, the potent anti-arrhythmic drug amiodarone $(1 \mu \mathrm{M})$ used as a TR inhibitor (Van Beeren et al. 1996), prevented the $\mathrm{T}_{3}$ effects (Figs 1D and 2). However, $\mathrm{T}_{3}$ did not protect hepatocytes from $1 \mu \mathrm{M}$ StSp-induced apoptosis (Fig. 1C) that activated the mitochondrial death pathway independently from death receptors. Our results indicate that in hepatocytes, $\mathrm{T}_{3}$ selectively inhibits DRL-mediated apoptosis, and the observed protection does not result from a general inhibitory effect on cell death.
Next, we investigated whether new protein synthesis is required for the anti-apoptotic effect of $\mathrm{T}_{3}$. As shown in Figs $1 \mathrm{D}$ and $2, \mathrm{~T}_{3}$-mediated protection from $\mathrm{TNF} \boldsymbol{\alpha}$-induced apoptosis occurred equally well in the presence or in the absence of cycloheximide (CHX; $60 \mu \mathrm{g} / \mathrm{ml})$, indicating that the $T_{3}$ protective effect was independent of new protein synthesis. It was also independent of activation of transcription because we have added ActD in all experiments along with application of $\mathrm{TNF} \alpha / \mathrm{Fas}$ to sensitize hepatocytes to apoptosis (Ding \& Yin 2004). Therefore, the involvement of cytoplasmic, non-genomic signaling pathways has to be considered. Indeed, anti-apoptotic and mitogenic effects of THs were associated with the activation of several nongenomic mechanisms, including activation of PKA, ERK, and NHE in different cells (Yen 2001, Davis \&Davis 2002, D'Arezzo et al. 2004, Furumoto et al. 2005, Incerpi 2005). In our experiments, the THs-induced anti-Fas protective effect was reversed by pretreatment $(30 \mathrm{~min})$ and co-incubation with PKA inhibitor KT-5720 (500 nM), ERK activation inhibitor U0126 $(10 \mu \mathrm{M})$, and NHE inhibitor EIPA $(60 \mu \mathrm{M}$; Figs 1 and 2). KT-5720, U0126, and EIPA have been tested separately and did not affect cell viability or DNA integrity during overnight treatment (data not shown).

Successful inhibition of $\mathrm{T}_{3}$ effects by KT-5720 indicated an involvement of cAMP/PKA into $\mathrm{T}_{3}$-induced anti-apoptotic signaling. To elucidate whether this anti-apoptotic effect of THs is causally linked to the increases in cAMP induced by $\mathrm{T}_{3}$, we examined the effect of $100 \mu \mathrm{M}$ 8-bromoadenosine $3^{\prime}, 5^{\prime}$-cyclic monophosphate (Br-cAMP) on Fas-induced apoptosis. Pretreatment with Br-cAMP significantly reduced the number of apoptotic cells compared with TNFa/Fastreated controls. However, we have not observed an additive effect of Br-cAMP and $\mathrm{T}_{3}$ (Fig. 1D).

Hepatocyte apoptosis initiated by DRLs-like TNF $\alpha$ or Fas elicits the recruitment of several cellular pathways resulting in the activation of caspase- 8 and caspase-3, translocation of Bid into mitochondria with subsequent cytochrome $c$ release (Van Beeren et al. 1996). The cytosolic cytochrome $c$ accumulation results in the formation of the apoptosome and DNA degradation (Ding \& Yin 2004). Therefore, DNA fragmentation and caspase activation have been described as apoptosis markers in hepatocytes challenged with Fas/TNFa/ActD (Ding \& Yin 2004). In our experiments, $\mathrm{T}_{3}$ prevented Fas-induced caspase- 8 activation (Fig. 2). The protective effect of $\mathrm{T}_{3}$ was inhibited in the presence of KT-5720, U0126, and EIPA indicating the necessity of PKA, ERK, and NHE activation to overbalance Fas-induced apoptosis and prevent caspase-8 activation. Protective $T_{3}$ effects have also been confirmed using the DNA fragmentation assay (Fig. 2B).

\section{$T_{3}$-induced increases in $C A M P$ and $P K A$ activation are important for prevention of Fas-induced apoptosis}

In hepatocytes, cAMP protected against apoptosis induced by TNF and Fas ligands (Van Beeren et al. 1996, Fladmark et al. 
1997, Li et al. 2000). To confirm the cAMP participation in $\mathrm{T}_{3^{-}}$ mediated effects, we next examined how $\mathrm{T}_{3}$ affects the cellular cAMP content. Dose-response studies revealed that low, physiological concentrations of $\mathrm{T}_{3}$, but not $\mathrm{rT}_{3}$ caused a sixfold increase in the cellular cAMP content (Fig. 3). The effect was blocked by pretreatment with amiodarone. Used as a positive control, forskolin $(5 \mu \mathrm{M})$ increased cAMP nine times above the basal level. Intracellular cAMP levels returned to the control level by $6 \mathrm{~h}$ despite continued exposure to hormonal ligands.

To assess whether protein and RNA synthesis were required for the stimulatory effect of $\mathrm{T}_{3}$ on intracellular cAMP concentration, cells were pretreated with $\mathrm{CHX}$ and ActD for $60 \mathrm{~min}$ prior to the addition of the hormone. CHX/ActDtreated cells showed no inhibition of $\mathrm{T}_{3}$-induced stimulation of cAMP, although the inhibitors prevented protein and RNA synthesis by $>95 \%$ (data not shown). This implies that $\mathrm{T}_{3^{-}}$ induced stimulation of cAMP accumulation does not require RNA or protein synthesis. The early time course of cAMP increase is also consistent with the apparent absence of a requirement for RNA synthesis.

In classic signaling cascades, cAMP activates PKA, a cAMP-dependent serine threonine kinase, which in turn regulates intracellular pathways via phosphorylation of signaling intermediates (Kopperud et al. 2003). Since $T_{3}$ increased intracellular cAMP, we asked whether the changes in cAMP were significant enough to affect the activation of PKA. We have measured PKA activity stimulated by $T_{3}$. As shown in Fig. 3, $\mathrm{T}_{3}$ induced activation of PKA that decreased to baseline levels by $24 \mathrm{~h}$. The specificity of this response was confirmed by the finding that amiodarone blocked $\mathrm{T}_{3}$ effects and $\mathrm{rT}_{3}$ did not stimulate PKA activity (Fig. 3C). The $\mathrm{T}_{3}$-induced increase in PKA activity was not affected by $T N F \alpha$ (Fig. 3D). These data suggest that $T_{3}$ signaling is a potential source of PKA activation that might be required for inhibition of DRL-dependent apoptosis in hepatocytes.
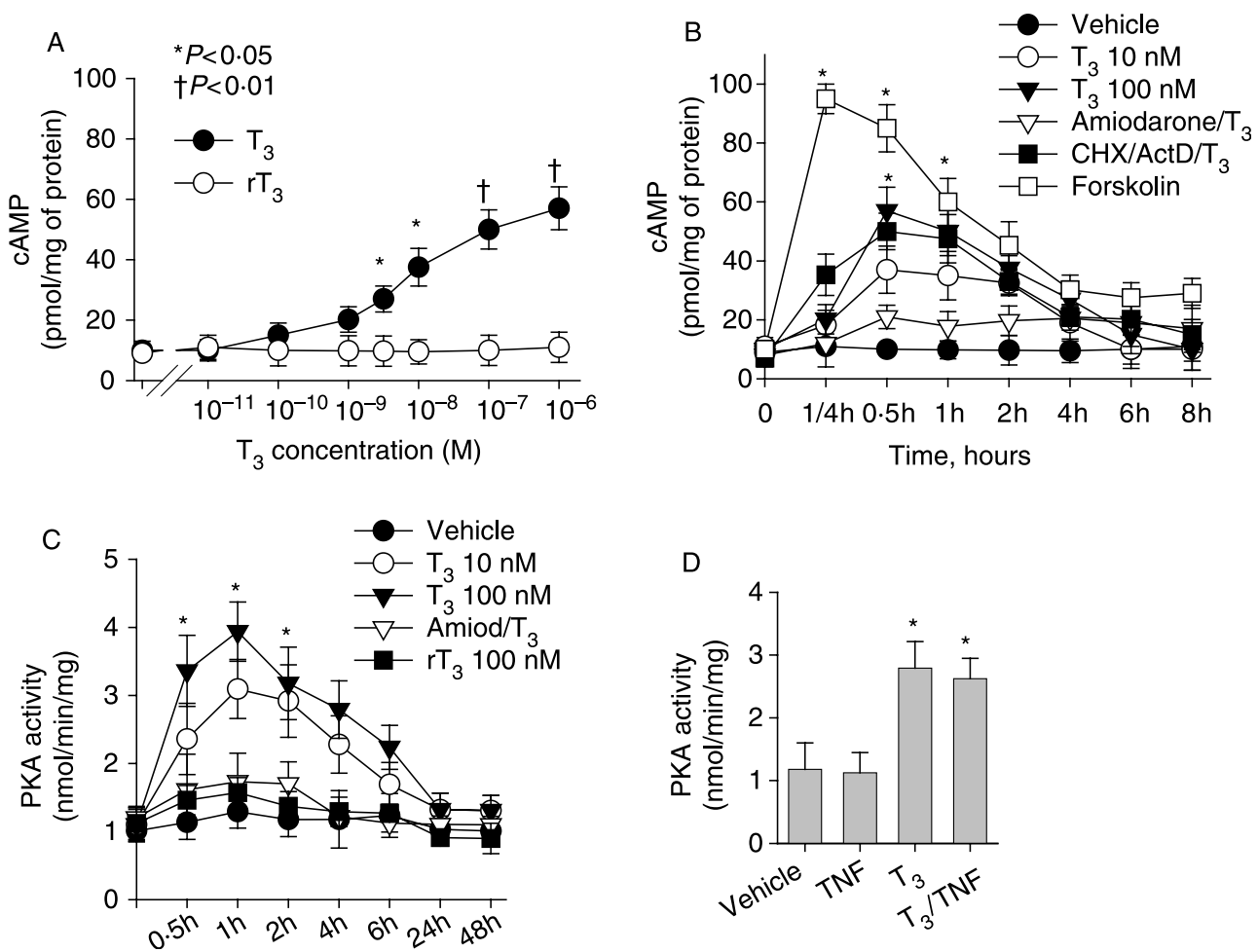

Figure $3 T_{3}$ stimulates increases in the cellular cAMP content and PKA activity in mouse hepatocytes. (A) $T_{3}$ or $r T_{3}$ was applied dose dependently for $60 \mathrm{~min}$. Intracellular CAMP content was determined by RIA. ${ }^{*} P<0 \cdot 05$ and ${ }^{\dagger} P<0 \cdot 01$ indicate statistically significant effects of $\mathrm{T}_{3}$ treatment compared with $\mathrm{rT}_{3}$-treated cells. (B) Time-dependent changes in intracellular CAMP have been measured after treatment with or without 10 or $100 \mathrm{nM} \mathrm{T}_{3}, 1 \mu \mathrm{M}$ amiodarone (30-min pretreatment), ActD $(0 \cdot 2 \mu \mathrm{g} / \mathrm{ml}), 60 \mu \mathrm{g} / \mathrm{ml} \mathrm{CHX} \mathrm{(60-min} \mathrm{pretreatment),} \mathrm{or} \mathrm{with} 5 \mu \mathrm{M}$ forskolin. Inhibitors were added before treatment with $100 \mathrm{nM} \mathrm{T}_{3} \cdot{ }^{* P}<0 \cdot 05 \mathrm{~T}_{3}$ treatments versus vehicle-treated controls. (C) PKA activity was measured in hepatocytes at the indicated time points using 10 or $100 \mathrm{nM} \mathrm{T}_{3}, 100 \mathrm{nM} \mathrm{rT}_{3}$, and $1 \mu \mathrm{M}$ amiodarone (Amiod). PKA activity was determined by measuring incorporation of radiolabeled phosphate into a PKA-substrate peptide (Kemptide) and subtracting background counts obtained in the absence of substrate. (D) Bar graphs represent data obtained from four individual PKA assay experiments after 1-h stimulation with the marked reagents as follows: $10 \mathrm{nM} \mathrm{T}_{3}, 10 \mathrm{ng} / \mathrm{ml} \mathrm{TNF} \alpha \pm \operatorname{ActD}(0 \cdot 2 \mu \mathrm{g} / \mathrm{ml})$, separately and combined. Results are expressed as means \pm s.D. $* P<0 \cdot 05$ versus vehicle-treated controls. 
$T_{3}$ activates ERK to suppress Fas-mediated apoptosis

ERK is a member of the MAPK family that participates in mitogenic signaling through complex phosphorylation cascades converting cell surface signals into nuclear transcription programs. Induction of ERK signaling by cAMP/PKAdependent pathway has been shown (Kopperud et al. 2003, Rudolph et al. 2004). Importantly, ERK is also known to attenuate Fas-mediated apoptosis in hepatocytes (Sautin et al. 2001). We have detected that the inhibition of ERK activation by $\mathrm{U} 0126$ suppressed the $\mathrm{T}_{3}$-dependent protection against Fas-induced apoptosis (Figs 1 and 2).

To confirm the ERK-dependent mechanisms of $\mathrm{T}_{3}$ mediated prevention of Fas-induced apoptosis, we addressed the activation of MAPK as a potential target for $T_{3}$ action. In our experiments, $\mathrm{T}_{3}$ markedly induced the phosphorylation of ERK in hepatocytes, starting at $30 \mathrm{~min}$ and lasting up to $10 \mathrm{~h}$ (Fig. 4A). The stimulation of ERK phosphorylation by $\mathrm{T}_{3}$ also occurred in the presence of the apoptotic trigger (Fas/TNF $\alpha$; Fig. 4B). We have not detected any significant increases in ERK activation after time-course treatment (15 min to $4 \mathrm{~h}$ ) with TNF $\alpha$ or Fas/ActD in primary mouse hepatocytes (data not shown). U0126, used as a positive control, effectively inhibited $\mathrm{T}_{3}$-dependent ERK activation (Fig. 4B). PKA inhibition by KT-5720 also prevented $\mathrm{T}_{3^{-}}$ induced ERK activation suggesting PKA activation is upstream of ERK signaling. Together, these data supported our findings that $\mathrm{T}_{3}$ inhibits Fas-mediated apoptosis in hepatocytes through activation of the ERK signaling pathway by a PKA-dependent mechanism.

\section{$T_{3}$ prevents $T N F \alpha$-induced intracellular acidification}

Low pH-dependent (acidic) nucleases are often involved in intranucleosomal genome degradation. Fas-ligands have been shown to induce not only DNA degradation, but also cytosole acidification via inhibition of NHE (Gottlieb et al. 1996). In our experiment, NHE inhibitor EIPA abrogated $\mathrm{T}_{3}$-dependent anti-apoptotic effects indicating the importance of pHin regulation for cell survival (Figs 1 and 2). Our data suggested that $T_{3}$ effects could be mediated by activation of the NHE and subsequent intracellular alkalinization.

To assess whether $\mathrm{T}_{3}$ regulates intracellular $\mathrm{pH}$ in hepatocytes, we performed conventional BCECF fluorescence measurements. We analyzed the distribution of TNF $\alpha /$ Fas- and vehicle-treated cells according to their pHin using flow cytometry and fluorimetry. Treatment of hepatocytes with TNF $\alpha$ or Fas led to the appearance of a subpopulation of cells with a more acidic pHin than vehicletreated cells (Fig. 5) as it was noted previously that exposure to DRL-stimulated decreases in pHin (Gottlieb et al. 1996, D'Arezzo et al. 2004). In contrast, shift of the main cell population towards alkalinized $\mathrm{pH}$ was observed after the addition of physiological concentrations of $\mathrm{T}_{3}$ indicating significant rise in the pHin (Fig. 5). Using a fluorimetric assay, we confirmed these data and found that $\mathrm{T}_{3}$ induced gradual increases of hepatocyte pHin. EIPA caused suppression of the $\mathrm{T}_{3}$-induced increases in pHin. Treatment with $\mathrm{rT}_{3}$ had no effect on hepatocyte $\mathrm{pHin}$. Our experiments were carried out in $\mathrm{HCO}_{3}$-free media, which renders the NHE as the main mechanism for regulation of pHin (Gottlieb et al. 1996).

A

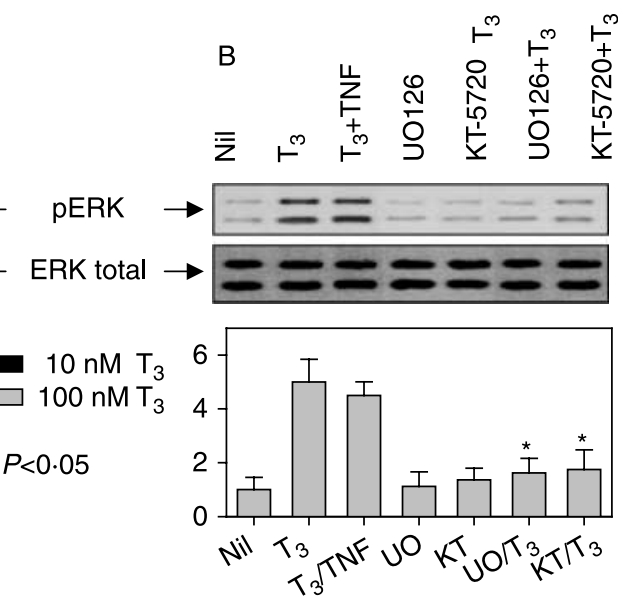

Figure $4 \mathrm{~T}_{3}$ induces ERK activation in mouse hepatocytes. (A) Hepatocytes were treated with $10 \mathrm{nM}$ $\mathrm{T}_{3}$ for various periods of time. Bar graphs represent normalized band intensities obtained from four individual western blotting experiments with 10 and $100 \mathrm{nM} \mathrm{T}_{3}$. (B) Hepatocytes were treated with $100 \mathrm{nM} \mathrm{T}_{3}(1 \mathrm{~h}), 10 \mathrm{ng} / \mathrm{ml} \mathrm{TNF} \alpha(4 \mathrm{~h}), 500 \mathrm{nM} \mathrm{KT}-5720$ (30 min), or $10 \mu \mathrm{M} \cup 0126$ (30 min), as marked. Cell lysates were subjected to $12 \%$ SDS-PAGE and probed with anti-phosphorylated ERK (pERK; the upper panels). The filter was stripped and reprobed using anti-ERK total (the lower panels) antibodies. Representative blots are shown, and the results were verified in three additional independent experiments. Bar graphs represent band intensities obtained from three individual experiments. Results were normalized by total ERK and expressed as means \pm s.D. ${ }^{*} P<0 \cdot 05$ versus zero time treatment or nil. 

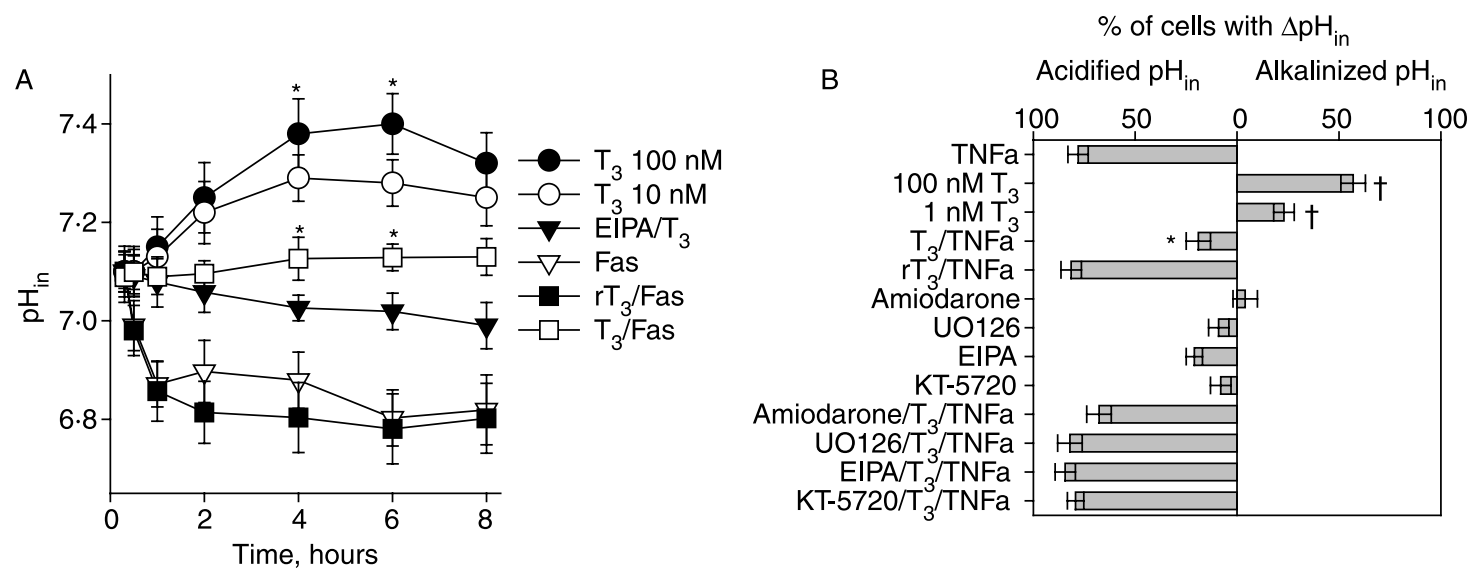

Figure $5 \mathrm{~T}_{3}$ changes pHin in mouse hepatocytes. (A) Time course of pHin changes was specific for $\mathrm{T}_{3}$ and blocked by EIPA that was determined by fluorimetric method as described in Materials and Methods. $T_{3}$, but not $r T_{3}$ pretreatment inhibited Fasinduced acidification. Used reagents and concentrations: 10 and $100 \mathrm{nM} \mathrm{T} / \mathrm{rT}_{3}, 0 \cdot 5 \mu \mathrm{g} / \mathrm{ml} \mathrm{Fas,} 0 \cdot 2 \mu \mathrm{g} / \mathrm{ml} \mathrm{ActD,} 60 \mu \mathrm{M}$ EIPA separately and combined. (B) $\mathrm{T}_{3}$ induces intracellular alkalinization and prevents Fas-dependent acidification detected by flow cytometry analysis using BCECF-loaded mouse hepatocytes. The bar graphs represent statistically analyzed data obtained from four individual experiments after 4-h stimulation. Used concentrations and time of treatment as described in Fig. 1D. All inhibitors were combined with $100 \mathrm{nM} \mathrm{T}_{3}$. Results are expressed as means \pm s.D. $* P<0 \cdot 05$ (Fas- or $\mathrm{T}_{3}$-treated cells versus nil), ${ }^{+} P<0 \cdot 01$ (Fas-treated versus $T_{3}$-pretreated cells).

Control application of EIPA alone induced slow acidification over 3-h treatment (data not shown).

As evident from flow cytometry analysis of mouse hepatocytes, $\mathrm{T}_{3}$ induced cytosolic alkalinization contrary to Fas stimulation that was marked by cytosolic acidification. $T_{3}$ pretreatment, but not $\mathrm{rT}_{3}$, prevented Fas effects and markedly increased $\mathrm{pHin}$ when compared with $\mathrm{TNF} \alpha /$ Fas-treatment alone (Fig. 5B). EIPA abrogated $\mathrm{T}_{3}$-induced $\mathrm{pH}$ effects. These results suggest that $T_{3}$ can compensate the DRLsdependent inhibition of the NHE and prevent acute cytosolic acidification in mouse hepatocytes.

\section{Hypothyroidism enhances Fas-induced apoptosis in vivo}

The liver of mice is particularly sensitive in vivo to anti-Fas antibodies, which cause liver apoptosis with a phenotype that resembles fulminant hepatitis marked by activation of caspases (Ogasawara et al. 1993). We addressed the activation of caspase-8 in livers extracted from hypothyroid (thyroidectomized) and euthyroid mice. The thyroidectomized animals injected with placebo were severely hypothyroid with decreased $\mathrm{T}_{4} / \mathrm{T}_{3}$ levels $(5 \pm 2.4$ and $0 \cdot 2 \pm 0.38 \mathrm{ng} / \mathrm{ml}$ plasma). $\mathrm{T}_{4}$ and $\mathrm{T}_{3}$ blood concentrations in euthyroid mice were $60 \pm 14$ and $1.5 \pm 0.4 \mathrm{ng} / \mathrm{ml}$ plasma respectively. AntiFas antibodies $(0 \cdot 15 \mu \mathrm{g} / \mathrm{g}$ body weight $)$ or TNF $\alpha(0 \cdot 1 \mu \mathrm{g} / \mathrm{g}$ body weight) at non-lethal concentrations were injected 6 or $10 \mathrm{~h}$ before liver extraction. At $6 \mathrm{~h}$ after injection of Fas in vivo, as shown in Fig. 6, we could detect $20 \pm 7 \%$ increases in activation of caspase- 8 in hepatocytes from euthyroid animals. TNF $\alpha$ did not induce detectable caspase- 8 activation under these experimental conditions. However, Fas/TNF $\alpha$ effect was accelerated during 10-h exposure. Nevertheless, the group of animals survived well under the experimental conditions and was relatively resistant to Fas-mediated apoptosis. Hypothyroid animals demonstrated significant adverse response to $\mathrm{TNF} \alpha$ and anti-Fas treatment. We detected an increased sensitivity to Fas-mediated death by increased caspase- 8 cleavage in hypothyroid when compared with euthyroid mice. The increased sensitivity to Fas antibodies suggested an intrinsic change in the Fas cell death pathway. The increased damage of hepatocytes in hypothyroid mice after anti-Fas treatment in vivo was further confirmed by the significantly elevated serum AST and ALT levels when compared with control euthyroid mice (Table 1). However, as the time passed, AST and ALT levels increased slightly further in the euthyroid mice as well, but to a significantly lesser degree than in hypothyroid animals. These data implied that livers from hypothyroid mice are more sensitive to an otherwise non-lethal dose of anti-Fas antibodies.

These findings were not related to an enhanced cell surface expression of Fas (Fig. 6). Neither did we find a difference in the hepatic expression of cFLIP (Fig. 6B), which interferes with the autoproteolytical maturation of Fas-FADD-bound caspase-8 proximal in the Fas apoptotic pathway (Irmler et al. 1997).

\section{Discussion}

THs have been shown to modulate fundamental processes associated with development, including cell proliferation, differentiation, and apoptosis in nearly all tissues (Feng et al. 2000, Yen 2001, Furumoto et al. 2005). Regarding hepatic homeostasis, it has recently been detected that thyroid status strongly impacted liver regeneration altering the expression 
A

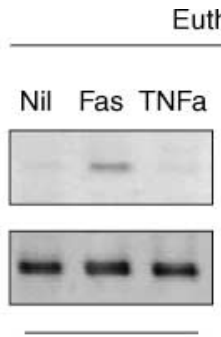

$6 \mathrm{~h}$
Euthyroid

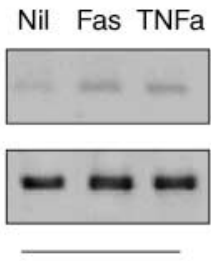

$10 \mathrm{~h}$
Hypothyroid

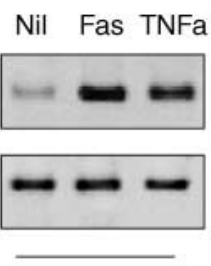

$6 \mathrm{~h}$

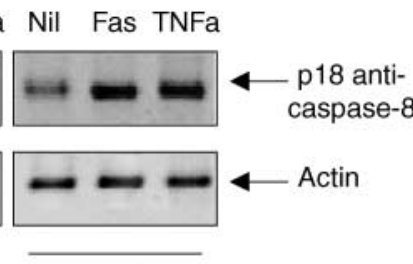

$10 \mathrm{~h}$
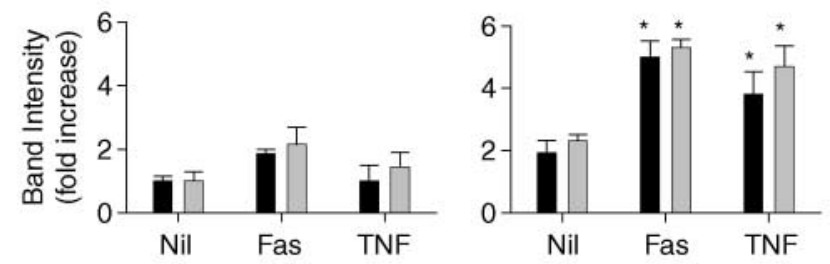

6 hours 10 hours

B

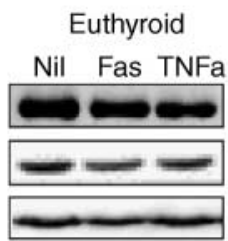

Hypothyroid

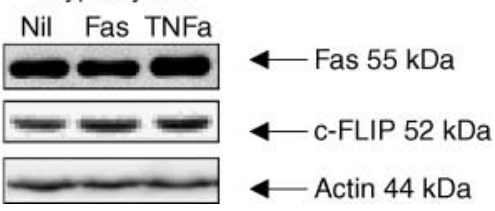

Figure 6 In vivo DRLs-induced apoptosis is enhanced in hypothyroid mice. (A) Hypothyroid mice demonstrated higher Fas/TNF $\alpha$-induced activation of caspase- 8 after exposure to Fas/TNF $\alpha$ for 6 and $10 \mathrm{~h}$. The bar graphs represent p18 caspase- 8 band intensities from three individual experiments. Results were normalized by actin and expressed as means \pm s.D. ${ }^{*} P<0 \cdot 05$ (DRLs-treated versus nil). (B) Fas and cFLIP expressions were determined by immunoblotting of hepatocyte lysates from in hypo- and euthyroid mice. All experiments have been repeated at least thrice and one representative experiment is shown.

and activity of proteins involved in the cell-cycle control (Francavilla et al. 1994, Feng et al. 2000, Alisi et al. 2005). Although THs are known to exert many of their effects via classical regulation of gene transcription, a large number of their actions occur rapidly and are unaffected by inhibitors of transcription and protein synthesis (Yen 2001, Davis \& Davis 2002, Incerpi 2005). Analyzing available data indicated that thyroid status influences sensitivity to apoptosis (Lin et al. 1999, Qi et al. 1999, Antonelli et al. 2004, Laoag-Fernandez et al. 2004, Verga Falzacappa et al. 2006), we questioned whether $\mathrm{T}_{3}$-activated signaling could suppress DRLs-induced apoptosis. In this study, we found that THs counteract apoptotic effects of Fas/TNF and prevent hepatocyte apoptosis in a rapid non-genomic manner independent of transcriptional activity (Figs 1 and 2). $\mathrm{T}_{3}$ effects resulted in inhibition of DRLs-induced annexin $V$ labeling, caspase-8 activation, and DNA degradation. As $\mathrm{T}_{3}$-mediated protection is independent of new protein synthesis, it is probable that the observed inhibition of apoptosis upstream of caspase- 8 was due to post-translational mechanisms. We further analyzed the intracellular signaling by which THs modulated DRLs-induced apoptosis in hepatocytes. We found that $T_{3}$ affected several intracellular targets, such as production of cAMP, PKA, ERK, and pHin.

We detected that $T_{3}$ dose- and time-dependently increased cellular content of cAMP and activated PKA in hepatocytes

Table 1 Effect of a single i.p. injection of anti-Fas antibodies on serum alanine aminotransferase (ALT) and aspartate aminotransferase (AST) levels in hypothyroid and euthyroid mice. Values are expressed as means \pm s.D. ( $n=6$ for the saline-treated controls, while $n=10$ for the anti-Fas-treated groups).

\begin{tabular}{|c|c|c|c|}
\hline & Treatment & ALT (U/ml) & AST (U/ml) \\
\hline \multicolumn{4}{|l|}{ Mice } \\
\hline \multirow[t]{3}{*}{ Euthyroid } & Saline & $87 \pm 43$ & $172 \pm 84$ \\
\hline & Anti-Fas $6 \mathrm{~h}$ & $21 \overline{78} \pm 1023^{*}$ & $156 \overline{7} \pm 927^{*}$ \\
\hline & Anti-Fas $10 \mathrm{~h}$ & $4108 \pm 2256$ & $3212 \pm 1986$ \\
\hline \multirow[t]{3}{*}{ Hypothyroid } & Saline & $116 \pm 41$ & $398 \pm 276$ \\
\hline & Anti-Fas $6 \mathrm{~h}$ & $12049 \pm 5698$ & $8696 \pm 3955$ \\
\hline & Anti-Fas $10 \mathrm{~h}$ & $15634 \pm 5994$ & $1022 \overline{6} \pm 4899$ \\
\hline
\end{tabular}

Note: All mice were treated intraperitoneally with either saline or anti-Fas antibodies $(0 \cdot 15 \mu \mathrm{g} / \mathrm{g}$ body weight). *Statistically different from the anti-Fastreated hypothyroid mice as determined by non-paired $t$-test $(P<0 \cdot 05)$. 
(Fig. 3). Our observations are consistent with previous reports regarding enhanced intracellular cAMP content in different cells after THs application (Yen 2001, Shih et al. 2004). THs modulated the activity of phosphodiesterase (Morgan et al. 1982) and mimicked the effects of cAMP-inducing hormones (Muller \& Seitz 1983, Daza et al. 1997). Furthermore, cAMPinduced PKA activation has been shown to mediate THs effects (Lin et al. 1999), such as potentiation of growth hormone receptor signaling in cancer cells (Shih et al. 2004). Consistently, we found that the activation of PKA is necessary for $\mathrm{T}_{3}$-initiated apoptosis prevention in hepatocytes. In our experiments (Fig. 2), the treatment of hepatocytes with Fas resulted in apoptosis induction and generation of the p18 active form of caspase- 8 , which are strongly inhibited in the presence of $\mathrm{T}_{3}$ or cAMP. Pretreatment of the cells with the PKA inhibitor KT-5720 abolished the ability of $\mathrm{T}_{3}$ to reduce caspase- 8 activation and inhibit apoptosis. These results have been confirmed in annexin $\mathrm{V}$ and DNA fragmentation assays (Figs 1 and 2).

PKA and its activator cAMP are established mediators of differential sensitivity to apoptosis (Van Beeren et al. 1996, Fladmark et al. 1997, Kopperud et al. 2003, Li et al. 2000). Increases in intracellular cAMP have been shown to prevent Fas-induced apoptosis in hepatocytes (Van Beeren et al. 1996, Fladmark et al. 1997). Moreover, activated PKA induced a prolonged stimulation of hepatocyte proliferation (Kopperud et al. 2003). Beyond PKA signaling, an increase in intracellular cAMP induced distinct mechanisms of anti-apoptosis, such as phosphorylation of Bad (Harada et al. 1999), glycogen synthase kinase-3 (Feng et al. 2000), and Akt pathway (Kopperud et al. 2003). Therefore, we cannot exclude the possibility that cAMP/PKA might also regulate additional steps in the $T_{3}$ signaling cascade.

There are many possible targets for a modulation of the DRL signaling, although only a few protein synthesisindependent signal-based mechanisms that regulate DRLdependent apoptosis have been reported. In this case, MAPK/ERK signaling was shown to phosphorylate DRL receptors directly, thereby causing inhibition of its cytotoxic ability (Cottin et al. 1999). We detected ERK activation in response to different concentrations of $\mathrm{T}_{3}$ (Fig. 4). Inhibition of ERK activation by MEK inhibitor U0126 significantly prevented $\mathrm{T}_{3}$ anti-apoptotic effects. Our results are consistent with the recently published in vivo data on the analysis of the phosphorylated forms of ERK. It has been revealed that ERK phosphorylation is induced during hepatic regeneration in euthyroid and hyperthyroid rats, whereas it is negatively regulated in hypothyroid animals (Alisi et al. 2004, 2005). Supportingly, several groups found that THs initiated nongenomic induction of ERK via putative membrane GPCR (Lin et al. 1999, Shih et al. 2004). Whether $\mathrm{T}_{3}$ prevents DRLs-induced apoptosis through GPCR remains to be determined.

ERK activity might be sufficient to trigger the THs protective effect as was shown for other ERK-activating agents (Sautin et al. 2001). However, $\mathrm{T}_{3}$-induced activation of
ERK was blocked by PKA inhibition (Fig. 4B). It appears that PKA activation is required for THs-promoted ERK activation and apoptosis prevention. Therefore, we suggest that the increases in intracellular cAMP and the activation of PKA are possible upstream mediators of ERK activation in response to $\mathrm{T}_{3}$. Indeed, ERK activation has been linked to cAMP production (Rudolph et al. 2004) and PKA activation (Saxena et al. 1999). Furthermore, ERK was proposed as a downstream effector of cAMP signaling linked to hepatocyte survival via activation of the small GTPases, Rap1/2 (Caron 2003).

One of the downstream targets of PKA and ERK activation is the regulation of intracellular pHin. It is well known that plasma membrane of hepatocytes has a system of membrane transporters that supports neutral pHin (D'Arezzo et al. 2004). Fas-induced apoptosis has been reported to induce cytosolic acidification via inhibition of NHE (Gottlieb et al. 1996). Acidic pHin stimulates endonuclease activity and DNA fragmentation (Gottlieb et al. 1996). Our presented results confirmed that Fas/TNF are able to induce cytosolic acidification. In contrast, $\mathrm{T}_{3}$-treated cells respond with a significant increase in $\mathrm{pHin}$ responsible for the recovery and/or maintenance of normal pHin (Fig. 5). We have observed that Fas-induced caspase- 8 activation and DNA degradation can be prevented by $\mathrm{T}_{3}$ that is also able to block Fas-induced intracellular acidification. The $\mathrm{T}_{3}$ effect on the intracellular $\mathrm{pH}$ was completely blocked by EIPA - the specific NHE antiport inhibitor.

Cytosolic alkalinization and activation of NHE are known as non-genomic anti-apoptotic mechanisms. For instance, cAMP and PKA have been shown to activate NHE (Borgese et al. 1992, Caron 2003). Our results are in agreement with these studies and indicate that THs signaling is an important modulator of $\mathrm{pHin}$ that impacted hepatocyte survival. The raise in $\mathrm{pHin}$ induced by $\mathrm{T}_{3}$ should be sufficient to stop DNA degradation and/or prevent further activation of the endonuclease. We also found that $\mathrm{T}_{3}$-induced activation of PKA and ERK signaling are necessary for regulation of intracellular pHin in hepatocytes because the PKA and ERK inhibitors, KT-5720 and U0126, blocked $\mathrm{T}_{3}$-initiated pHin effects (Fig. 5).

Our results are in agreement with findings that NHE might be stimulated via the mechanism of direct phosphorylation of NHE either by ERK itself or by p90rsk, a newly described ERK-activated kinase (Moor \& Fliegel 1999). Furthermore, THs were shown to activate the NHE by a rapid, nongenomic mechanism in rat skeletal muscle (D'Arezzo et al. 2004), L-6 myoblasts (D'Arezzo et al. 2004), and cat atrial myocytes (Wang et al. 2003). This $\mathrm{T}_{3}$ effect is thought to be mediated non-genomically via activation of ERK (Wang et al. 2003, D’Arezzo et al. 2004).

DRL-induced hepatic apoptosis is considered as an important cause for a variety of liver diseases, such as viral hepatitis, cholestasis, and ischemic or septic liver injury (Luedde et al. 2002). For instance, playing a primary role in inflammation TNF $\alpha$ mediates severe hepatocellular damage 
(Zang et al. 2000, Ding \& Yin 2004). Therefore, the suppression of TNF $\alpha$-induced hepatocyte apoptosis in clinical aspects is critical. Our in vivo data demonstrated that euthyroid mice are more resistant to $\mathrm{TNF} \alpha / \mathrm{Fas}-$ induced apoptosis when compared with hypothyroid animals (Fig. 6). The level of caspase- 8 activation was increased in hypothyroid compared with euthyroid mice after Fas/TNF $\alpha$ injections. The significantly elevated serum AST and ALT levels in hypothyroid mice confirmed the increased hepatocyte sensitivity to Fas-induced apoptosis (Table 1). Taken together, all our results demonstrate that the THs-initiated inhibition of the DRL apoptotic signal occurs at the very proximal stages of apoptotic signaling because $\mathrm{T}_{3}$-induced signaling seems to suppress apoptosis before activation of caspase-8. Taken together, our in vitro and in vivo data indicate that $\mathrm{T}_{3^{-}}$ activated signaling pathway mediated by activation of PKA, ERK, and balanced pHin strongly enable survival of hepatocytes. Therefore, THs could be an important target in the therapeutic intervention that can block unwanted hepatocellular apoptotic cell death during inflammation and/ or septic liver failure.

\section{Acknowledgements}

This work was supported partially by the Edmund S Muskie/Freedom Support Act Fellowship Program (US Department of State; to O A S), Fogarty International Centre, National Institutes of Health (5D43TW00636 to D O C), and by the NYS Institute for Health and Environment. The authors declare that there is no conflict of interest that would prejudice the impartiality of this scientific work.

\section{References}

Alisi A, Spagnuolo S, Napoletano S, Spaziani A \& Leoni S 2004 Thyroid hormones regulate DNA-synthesis and cell-cycle proteins by activation of PKCalpha and p42/44 MAPK in chick embryo hepatocytes. Journal of Cell Physiology 201 259-265.

Alisi A, Demori I, Spagnuolo S, Pierantozzi E, Fugassa E \& Leoni S 2005 Thyroid status affects rat liver regeneration after partial hepatectomy by regulating cell cycle and apoptosis. Journal of Cell Physiology and Biochemistry 15 69-76.

Antonelli A, Ferri C, Pampana A, Fallahi P, Nesti C, Pasquini M, Marchi S \& Ferrannini E 2004 Thyroid disorders in chronic hepatitis C. American Journal of Medicine 117 10-13.

Borgese F, Sardet C, Cappadoro M, Pouyssegur J \& Motais R 1992 Cloning and expression of a cAMP-activated $\mathrm{Na}^{+} / \mathrm{H}^{+}$exchanger: evidence that the cytoplasmic domain mediates hormonal regulation. PNAS 89 6765-6769.

Caron E 2003 Cellular functions of the Rap1 GTP-binding protein: a pattern emerges. Journal of Cell Science 116 435-440.

Cottin V, Van Linden A \& Riches DW 1999 Phosphorylation of tumor necrosis factor receptor CD120a (p55) by p42(mapk/erk2) induces changes in its subcellular localization. Journal of Biological Chemistry 274 32975-32987.

D’Arezzo S, Incerpi S, Davis FB, Acconcia F, Marino M, Farias RN \& Davis PJ 2004 Rapid nongenomic effects of 3,5,3'-triiodo-L-thyronine on the intracellular $\mathrm{pH}$ of $\mathrm{L}-6$ myoblasts are mediated by intracellular calcium mobilisation and kinase pathways. Endocrinology 145 5694-5703.
Davis PJ \& Davis FB 2002 Nongenomic actions of thyroid hormone on the heart. Thyroid 12 459-466.

Daza FJ, Parilla R \& Martin-Requero A 1997 Influence of thyroid status on hepatic alpha 1-adrenoreceptor responsiveness. American Journal of Physiology 273 E1065-E1072.

Di Fulvio M, Coleoni AH, Pellizas CG \& Masini-Repiso AM 2000 Tri-iodothyronine induces proliferation in cultured bovine thyroid cells: evidence for the involvement of epidermal growth factor-associated tyrosine kinase activity. Journal of Endocrinology 166 173-182.

Ding WX \& Yin XM 2004 Dissection of the multiple mechanisms of TNF-alpha-induced apoptosis in liver injury. Journal of Cellular and Molecular Medicine 8 445-454.

Escobar-Morreale HF, del Rey FE, Obregon MJ \& de Escobar GM 1996 Only the combined treatment with thyroxine and triiodothyronine ensures euthyroidism in all tissues of the thyroidectomized rat. Endocrinology 137 2490-2502.

Feng X, Jiang Y, Meltzer P \& Yen PM 2000 Thyroid hormone regulation of hepatic genes in vivo detected by complementary DNA microarray. Molecular Endocrinology 14 947-955.

Fladmark K, Gjertsen B, Doskeland S \& Vintermyr O 1997 Fas/APO-1(CD95) induced apoptosis of primary hepatocytes is inhibited by cAMP. Biochemical and Biophysical Research Communications 232 20-25.

Francavilla A, Carr BI, Azzarone A, Polimeno L, Wang Z, Van Thiel DH, Subbotin V, Prelich JG \& Starzl TE 1994 Hepatocyte proliferation and gene expression induced by triiodothyronine in vivo and in vitro. Hepatology 20 1237-1241.

Furumoto H, Ying H, Chandramouli GV, Zhao L, Walker RL, Meltzer PS, Willingham MC \& Cheng SY 2005 An unliganded thyroid hormone beta receptor activates the cyclin D1/cyclin-dependent kinase/retinoblastoma/ E2F pathway and induces pituitary tumorigenesis. Molecular and Cellular Biology 25 124-135.

Gibson S, Tu S, Oyer R, Anderson SM \& Johnson GL 1999 Epidermal growth factor protects epithelial cells against Fas-induced apoptosis. Requirement for Akt activation. Journal of Biological Chemistry 274 17612-17618.

Gottlieb RA, Nordberg J, Skowronski E \& Babior BM 1996 Apoptosis induced in Jurkat cells by several agents is preceded by intracellular acidification. PNAS 93 654-658.

Harada H, Becknell B, Wilm M, Mann M, Huang LJ, Taylor SS, Scott JD \& Korsmeyer SJ 1999 Phosphorylation and inactivation of BAD by mitochondria-anchored protein kinase A. Molecular Cell 3 413-422.

Incerpi S 2005 Thyroid hormones: rapid reply by surface delivery only. Endocrinology 146 2861-2863.

Irmler M, Thome M, Hahne M, Schneider P, Hofmann K, Steiner V, Bodmer JL, Schroter M, Burns K, Mattmann C et al. 1997 Inhibition of death receptor signals by cellular FLIP. Nature 388 190-195.

Kopperud R, Krakstad C, Selheim F \& Doskeland SO 2003 cAMP effector mechanisms. Novel twists for an 'old' signaling system. FEBS Letters 546 121-126.

Laoag-Fernandez JB, Matsuo H, Murakoshi H, Hamada AL, Tsang BK \& Maruo T 2004 3,5,3'-Triiodothyronine down-regulates Fas and Fas ligand expression and suppresses caspase- 3 and poly (adenosine $5^{\prime}$-diphosphate-ribose) polymerase cleavage and apoptosis in early placental extravillous trophoblasts in vitro. Journal of Clinical Endocrinology and Metabolism 89 4069-4077.

Li J, Yang S \& Billiar T 2000 Cyclic nucleotides suppress tumor necrosis factor $\alpha$-mediated apoptosis by inhibiting caspase activation and cytochrome $c$ release in primary hepatocytes via a mechanism independent of Akt activation. Journal of Biological Chemistry 275 13026-13034.

Lin HY, Shih A, Davis FB \& Davis PJ 1999 Thyroid hormone promotes the phosphorylation of STAT3 and potentiates the action of epidermal growth factor in cultured cells. Biochemical Journal 338 427-432.

Luedde T, Liedtke C, Manns MP \& Trautwein C 2002 Losing balance: cytokine signaling and cell death in the context of hepatocyte injury and hepatic failure. European Cytokine Network 13 377-383. 
Malik R, Habib M, Tootle R \& Hodgson H 2005 Exogenous thyroid hormone induces liver enlargement, whilst maintaining regenerative potential - a study relevant to donor preconditioning. American Journal of Transplantation 5 1801-1807.

Moor AN \& Fliegel L 1999 Protein kinase-mediated regulation of the $\mathrm{Na}^{+} / \mathrm{H}^{+}$-exchanger in the rat myocardium by mitogen-activated protein kinase-dependent pathways. Journal of Biological Chemistry 274 22985-22992.

Morgan DW, Shaheen O, Keyes WG \& Heimberg M 1982 Modulation by thyroid status of hepatic low Km phosphodiesterase. Endocrinology 110 260-264.

Muller MJ \& Seitz HJ 1983 Interaction of thyroid hormones and cyclic AMP in the stimulation of hepatic gluconeogenesis. Biochimical et Biophysical Acta 756 360-368.

Musgrove E, Rugg C \& Hedley D 1986 Flow cytometric measurement of cytoplasmic $\mathrm{pH}$ : a critical evaluation of available fluorochromes. Cytometry 7 347-355.

Ogasawara J, Watanabe-Fukunaga R, Adachi M, Matsuzawa A, Kasugai T, Kitamura Y, Itoh N, Suda T \& Nagata S 1993 Lethal effect of the anti-Fas antibody in mice. Nature 364 806-809.

Qi JS, Yuan Y, Desai-Yajnik V \& Samuels HH 1999 Regulation of the mdm2 oncogene by thyroid hormone receptor. Molecular and Cellular Biology 19 864-872.

Rudolph JA, Poccia JL \& Cohen MB 2004 Cyclic AMP activation of the extracellular signal-regulated kinases 1 and 2: implications for intestinal cell survival through the transient inhibition of apoptosis. Journal of Biological Chemistry 279 14828-14834.

Sautin YY, Crawford JM \& Svetlov SI 2001 Enhancement of survival by LPA via Erk1/Erk2 and PI 3-kinase/Akt pathways in a murine hepatocyte cell line. American Journal of Physiology and Cellular Physiology 281 C2010-C2019.
Saxena M, Williams S, Tasken K \& Mustelin T 1999 Crosstalk between cAMP-dependent kinase and MAP kinase through a protein tyrosine phosphatase. Nature Cell Biology 1 305-311.

Shih A, Zhang S, Cao HJ, Tang HY, Davis FB, Davis PJ \& Lin HY 2004 Disparate effects of thyroid hormone on actions of epidermal growth factor and transforming growth factor-alpha are mediated by $3^{\prime}, 5^{\prime}$-cyclic adenosine $5^{\prime}$-monophosphate-dependent protein kinase II. Endocrinology 145 1708-1717.

Van Beeren HC, Bakker O \& Wiersinga WM 1996 Structure-function relationship of the inhibition of the $3,5,3^{\prime}$-triiodothyronine binding to the alpha1- and beta1-thyroid hormone receptor by amiodarone analogs. Endocrinology 137 2807-2814.

Verga Falzacappa C, Panacchia L, Bucci B, Stigliano A, Cavallo MG, Brunetti E, Toscano V \& Misiti S 2006 3,5,3'-triiodothyronine is a survival factor for pancreatic $\beta$-cells undergoing apoptosis. Journal of Cellular Physiology 206 309-321.

Wang YG, Dedkova EN, Fiening JP, Ojamaa K, Blatter LA \& Lipsius SL 2003 Acute exposure to thyroid hormone increases $\mathrm{Na}^{+}$current and intracellular $\mathrm{Ca}^{2+}$ in cat atrial myocytes. Journal of Physiology 546 491-499.

Yen PM 2001 Physiological and molecular basis of thyroid hormone action. Physiological Reviews 81 1097-1142.

Zang GQ, Zhou XQ, Yu H, Xie Q, Zhao GM, Wang B, Guo Q, Xiang YQ \& Liao D 2000 Effect of hepatocyte apoptosis induced by TNF-alpha on acute severe hepatitis in mouse models. World Journal of Gastroenterology 6 $688-692$.

Received 17 July 2006

Accepted 16 August 2006 